226 4) Zhang, J. Y., et al., Fuel, 83(1), 129-135 5 5) Yan, R., at al., Combust. \& Flame, 138(1-2), 20-29 $\quad$ 6) Gale, T. K., et al, Proceedings of the Combustion Institute, 30(2), 2999-3007 7) Diaz-Somoano, M., et al, Energy \& Fuels, 18(5), 1238-1242 8)Iwashita, A., et al, Fuel, 83(6), 631-638 9) Schofield, K., Proceedings of the Combustion Institute, 30(1), 1263-1271 10$)$ Zeng, H., et al, Fuel, 83(1), 143-146 11) Lillieblad, L., et al., Energy \& Fuels, 18(2), 410-417 12) Gayan, P., et al., Fuel, 83(3), 277-286 13) StyszkoGrochowiak, K., et al, Fuel, 83(13), 1847-1853 $\quad$ 14) Benetto, E., et al, Fuel, 83 (7-8), 957-970

\section{2 液体の燃焼}

内燃機関や燃焼炉などにおける液体燃料の燃焼形態は，ほ とんどの場合が噴霧燃焼である。この噴霧燃焼では，燃料の 微粒化, 混合気形成, 蒸発や熱・物質移動, 燃焼反応などの 複雑な物理化学的過程が関連している。さらに，炉壁や機関 内壁との干渉も大きな影響を与える。このように複雑な噴霧 燃焼の挙動を解明し, 制御するための研究や技術開発が継続 的に進められている。本節では平成 16 年度の液体燃料の燃焼 挙動に関する研究動向を概説する。

\section{1. 液体燃料の微粒化に関する研究}

噴霧燃焼の燃焼状態を制御して有害な燃焼生成物の低減を はかるために，燃料微粒化の研究は極めて重要である。特に， 周囲空気との混合気形成を促進し, 適切な燃焼状態を作り出 すためにも，微粒化技術の高度化が望まれる。このような然料 の微粒化技術に関連した研究として, ジェットエンジンバー ナ用噴射弁の微粒化改善の研究1)，直噴ガソリン噴射用スリッ トノズル噴霧 2) -4) やディーゼル噴射ノズル内の内部流動 5) 6) の研究などが報告された。

\section{2. 燃料液滴および噴霧燃焼の基礎的研究}

単一液滴や液滴列の燃焼特性を調べた研究も多数行われて いる。燃料液滴の蒸発に関する研究788)，木質バイオマススラ リー燃料の熱分解や燃焼挙動を取り扱ったものがある ${ }^{9)}$ 。ま た，例年に引き続き微小重力環境を利用した液滴燃焼の研究 も報告されている。例えば静電場の影響 10\} - 12) や添加物の影 響13)，液滴列の燃え広がりを調べたもの ${ }^{14)}$ などがある。液滴 のミクロ爆発挙動を取り扱った研究も多く見られた ${ }^{15) ~ 17) 。 さ ~}$ らに，燃料と空気の混合気中における液滴群の燃焼挙動を調 べた研究 ${ }^{18\rangle}$ も報告されている。

\section{3. エンジンにおける噴霧燃焼の研究}

平成16年度もエンジンにおける噴霧燃焼に関連した研究が 数多く公表されている。例えば超高過給ディーゼル燃焼の研 究 ${ }^{19)}$ や高スワールと燃料噴射制御を組み合わせた燃焼改善技 術20)が報告されている。また，昨年度に引き続き，通常の軽 油以外の燃料によるディーゼルエンジンの研究も盛んである。
アルコール燃料 ${ }^{21)} や \mathrm{GTL}$ 軽油 ${ }^{22)}$ ，メチルエステル燃料に関連

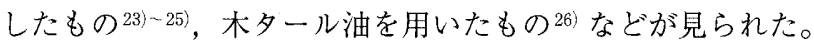
これら以外にも水エマルジョン燃料27) や乳化バイオディーゼ ル燃料 28）29）を用いた研究の報告もあった。

エンジン燃焼に関するモデリングの研究も見られた。例え ば，直噴ガソリンに抢けるスワール噴霧の研究 ${ }^{30)}$ ，ディーゼ ル燃焼のマルチゾーンモデル31)，粒径分布を考慮したオイ ラー型の多方程式モデルの研究 ${ }^{32)}$ が報告されている。

4. 燃焼過程で発生する粒子状物質とその計測に関する研究 平成16年度における液体燃焼関連の大きな特徵として，燃 焼過程で発生するすす粒子やナノサイズのPMの発生機構な らびにその計測技術に関する報告が数多く発表されたことが あげられる。本誌の解説として燃焼と環境の計測技術が特集 されたほか ${ }^{33)}$, 微粒子光学計測の国際会議 $(\mathrm{OPC} 2004)^{34)}$ や, 内燃機関における燃焼のモデリングと診断に関する国際会議 (COMODIA2004) ${ }^{35)}$ などに多くの報告が見られる。

論文として公表されたものとしては,ディーゼル然焼にお けるすす粒子の研究として，噴射圧や霉囲気条件の影響 36 ，す すの形態や粒径分布 ${ }^{37}$, 燃料中の芳香族成分の影響 ${ }^{38)}$ ，すす の形成モデルの検討 ${ }^{39}$ ) ${ }^{40)}$ ，粒子中のダイオキシン類 41 などに ついて調べたもの，さらに，二トロ多環芳香族炭化水素の生 成機構を調べたもの ${ }^{42)}$ などが発表された。また，レーザー誘 起赤熱発光を用いたすす濃度分布の研究 ${ }^{43}$ (4) も見られた。

ナノサイズの PM（以下単にナノ PM と呼ぶ）に関する報告 も多数行われた。これは，燃焼ガス中に含まれるナノPMが人 体に悪い影響を与える可能性があることから，早急に発生原 因の解明と抑制が求められているものである。このナノPMに ついては，その計測や評価手法についても研究途上であり，計 測法自身の評価を行った研究や試験法を検討したもの ${ }^{45}$ ) ${ }^{46)}$, ナノ PM の化学成分計測を解説したもの ${ }^{47)}$, DPF 装着時のナ ノPMの挙動を調べた研究48) などが見られた。また，ナノPM の前駆物質と考えられている多環芳香族炭化水素に関連した 報告 ${ }^{49)}$ も見られた。その他の液体燃料の燃焼に関する研究と して, プール火炎の研究 50) 51〉があげられる。

\section{5. まとめ}

以上のように基礎から応用的研究まで様々な研究が行われ ているが, 平成 16 年度の研究動向の特徵としては, DME や GTL，バイオマス燃料などの新燃料燃焼技術に関連する研究 が多いこと，ならびに燃焼過程で排出される微粒子に対する 関心が高まっていることがあげられよう。

\section{文 献: References}

1）山田ら, 日本機械学会論文集, B70 (700), 3257 2) 河村ら, 自動車 技術会論文集，35(2)，7 3)横田ら，自動車技術会論文集，35(3)，21， 4) 松村ら，自動車技術会論文集，35(4)，95）葛綿ら，自動車技術会論文 集，35(1)，39，6）暮綿ら，自動車技術会論文集，35(1)，45，7）角田 ら, 日本機械学会論文集, B70(697), 2447 8) K. Harstad, et. al, Comb.\& Flame, 137, 163 9) 木本ら，日本機械学会論文集，B70(699), 2899 10) 
K. Okai, et. al., Comb.\& Flame, 136, 390 11) 岡井ら, 日本機械学会論文集, B70 (695), 1842 12) 今村ら, 日本機械学会論文集, B70(691), $811 \quad 13$ ) J. H. Bae, et. al., Comb. \& Flame, 137, 148 14) 三上ら，日本燃焼学会誌，46 (135), 42 15) C. H. Wang, et. al., Comb.Sci.\& Tech., 176(1),71 16) 木本 ら, 日本機械学会論文集, B70(690), 532 17) 田中ら, 日本機械学会論 文集, B70 (694), 1577 18)浜崎ら，日本機械学会論文集，B70(697), 2441 19）青柳ら，自動車技術会論文集，35(3)，35 20）佐藤ら，自動車技術 会論文集, 35(2), 45 21) 齊藤ら, 日本機械学会論文集, B70(694), 1590 22）系中ら，自動車技術会論文集，35(3)，53 23）武田ら，日本機械学 会論文集，B70(689)，279 24）武田5，日本機械学会論文集，B70(691), $80325)$ 木下ら, 日本機械学会論文集, B70(690), 546 26) 山根ら, 自動車技術会論文集，35(1)，83 27）奇ら，日本機械学会論文集，B70 (689), 272 28)C. Jaqin ら，日本機械学会論文集，B70(695), 1878 29) 浜崎ら，日本機械学会論文集，B70(699), 2907 30) M. Takagi, et. al., Int. J. Engine Res., 5(1), $39 \quad$ 31) Y. Liu, et. al., Int. J. Engine Res., 5(1),71 32 3) F Laurent, et. al., Comb. Theory \& Modeling, 8, 385 33) 日本エネルギー学会誌, 83(9) 34) Proc. of 7 th International Congress on Optical Particle Characterization, OPC2004, Kyoto, Japan 35) Proc. of 6th Int. Symp. on Diagnostic and Modeling of Combustion in Internal Combustion Engine, Yokohama, Japan 36)L. M. Pickett, et. al., Comb. \& Flame, 138, 114 37)H. Song, et. al., $\begin{array}{lll}\text { J. of Energy Institute. 77, } 26 & \text { 38) T. C. Zannis et. al., J. of Energy Institute, 77, } 16\end{array}$ 39) F. Tao, et. al., Comb. \& Flame, 136, 270 40) Q. P. Tan, et. al., J. of Energy Institute, 77, 68 41) 是松如, 日本機械学会論文集, B70(697), 2462 42) 久米放，自動車技術会諭文集，35(2)，5943) 角田的，日本機械兴会諭 文集，B70(700)，3218 44)稻垣放，自動車技術会論文集，35(1)，89 45) 河今的，自動車技術会論文集，35(2)，73 46）小林方，自動車技術会喻 文集, 35(3),71 47) 出口ら, 日本燃燒学会誌, 46(137), 137 48) 李 ら, 自動車技術会論文集，35(3)，65 49）北村占，日本機械学会論文集， B70(696), 2220 50) 伊藤, 日本燃烊学会誌, 46(138), 209 51) 村松 ら, 日本燃焼学会誌, 46(137), 176

\section{3 気体の燃焼}

平成 16 年度は, 国際燃焼シンポジウムの開催年（シカゴ） であり，層流火炎，乱流火炎，化学反応機構，燃焼制御など の各分野に対して多くの研究がSymposium Volume ${ }^{11}$ に揭載さ れている。国内では，第 42 回燃焼シンポジウム 27 が岐皁で開 催された。それらの会議の内容は, 気体の燃焼の動向を調べ るのに最適である。今回は，層流火炎，乱流火炎㧍よび新燃 焼技術を中心に気体の燃焼の研究動向について第30回国際燃 焼シンポジウムに出席した感想を参考に紹介する。なお，第 30回国際燃焼シンポジウムの論文集は，2005年となっている が，会議の開催は，2004年 7 月であるので，平成16年度とし て取り扱うこととして問題がないと考えられる。

\section{1. 層流火炎}

国際会議，国内会議ともに，層流火炎のセッションは，多 く設定される傾向がここ数年続いている。例えば，10年前に
開催された第33回燃焼シンポジウム3)では，層流火炎のセッ ションが 3 件であったのに対して，第 42 回では 5 セッション となっている。これに対して，乱流火炎のセッションでは，第 33 回が 4 件であったが，第 42 回では， 3 件に減少している。 セッションの組み立て方により多少の増減が生じることはあ るが，層流火炎に関する研究が，盛んに行われている傾向が 確認できる。特に，顕著な傾向としては，やはり乱流火炎の 火炎片 (flamelet) としての位置づけの渦や伸張に関する研究 と edge flameや triple flame を対象にした火炎安定機構などに 関する研究の多さである。edge flameの形成方法については, 特徵のある場がいくつか提案されている。例えば, Amantini, G., et al. 4) ，対向流バーナーの中心軸に渦発生管を設置し，そ の洞を対向流中に形成される平面状の火炎に衝突させ，局所 的な消炎を誘発させた際に形成される edge flame を対象に消 炎とエッジ部分の火炎伝播機構に対する研究を行っている。 従来の研究では，乱流火炎の火炎片の基礎研究として検討が 加えられていた管状火炎を高速流中での保炎として適応させ るための研究が行われている。その結果， $130 \mathrm{~m} / \mathrm{s} の$ 高速流の 火炎を保炎することが可能であることが報告された5。この研 究は, 基礎研究用の火炎の展開研究として非常に興味深い研 究であり，今後の発展に期待したい。PIVやCARSなどの計測 技術を駆使した研究としては, Kim, N. ら ${ }^{67}$ が, 濃度勾配のあ る流れを複合スリットバーナーで作り，そこに形成される triple flame を対象に検讨を加えている。また，Takahashi, F., et al. ら ${ }^{7)}$ 8) は, $0 \mathrm{~g}$ から $1 \mathrm{~g}$ までの重力場に対して噴流拡散 火炎の火炎基部のC 3 反応モデルを用いたDNS（直接数值計 算）を行っている。着火に関する研究では, 渦中や伸張流を 対象とした水素空気拡散火炎の研究が多く行われている。例 えば, Zheng, X. L.ら ${ }^{9)}$ による渦混合層内での水素空気拡散火 炎の着火, Seiser, R.ら ${ }^{10)}$ による非定常伸張流中での水素空気 拡散火炎の着火などがある。水素燃料に関する研究としては, その燃焼速度の速さから，内燃機関の次世代燃料として着目 され，水素空気予混合ガスを対象に内燃機関内での燃焼状態 を考慮した燃焼速度に関する研究が多く行われている。例え ば，Verhelst，S.ら11) は，層流㧍よび非定常条件に扔ける水素 空気予混合火炎について燃焼速度と Markstiein 長さについて 検討を加えている。Markstiein長さを考慮に入れた燃焼速度に ついては, Johnston, R. J.ら ${ }^{12)}$ も様々な種類の炭化水素系燃料 に対して検討を加えている。しかしながら，燃料電池の持つ 高効率性には，既存の熱機関サイクルでは，太刀打ちできな いのが現状である。その他のテーマについても積極的に検討 が加えられていた。層流火炎を対象とした研究は，その応用 性と展開性から今後も盛んに行われる傾向である。

\section{2. 乱流火炎}

乱流火炎では，実験的研究より LES（Large Eddy Simulation）やDNS (Direct Numerical Simulation) を用いた火炎の 局所的な構造に関する研究が数多く行われる傾向にある。国 際燃焼シンポジウムでは, LESとDNSのセッションが設定さ れ，LESは 6 件, DNS は 7 件の論文が発表された。また, 招 